\title{
THE EFFECT OF ASSET GROWTH AND DEBT SOLVENCY ON STOCK PRICE VOLATILITY (CASE STUDY OF BANKING CORPORATIONS LISTED IN THE INDONESIA STOCK EXCHANGE FOR THE PERIOD OF 2011-2018)
}

\author{
Mario Yohanis Thomas ${ }^{1}$, Ventje Ilat $^{2}$ \\ ${ }^{1,2}$ Program Pendidikan Profesi Akuntansi, Fakultas Ekonomi dan Bisnis, Universitas Sam Ratulangi, Jl. Kampus \\ Bahu, Manado, 95115, Indonesia \\ E-mail: mythomas8796@gmail.com
}

\begin{abstract}
This study aims to determine the effect of asset growth and debt solvency on stock price volatility. The population in this study is financial sector companies listed as issuers of shares on the Indonesia Stock Exchange (IDX). The sample is taken by the purposive method so that there are 6 banking companies that meet the criteria. The research data is secondary data for the period 2011-2018 obtained from the Indonesia Stock Exchange. This study uses quantitative methods with multiple linear regression analysis techniques with t-test, $F$ test, and analysis of the coefficient of determination. Hypothesis test results show a significant effect on the asset growth variable and an insignificant effect on the debt solvency variable.
\end{abstract}

Keywords: asset growth; debt solvency; stock price volatility

JEL Classification: G11, G32, G33

Article info:

Received 21 May 2021

Revised 24 May 2021

Accepted 24 May 2021

Available online 24 May 2021

\section{INTRODUCTION}

Compared to the industrial revolution era, world business in the 4.0 era is increasingly dynamic and competitive, where now the role of technology and innovative steps in corporate management is a catalyst for the rapid development of the private sector. This condition has become clear with the proliferation of investment platforms that are portable and real-time, as well as an increasingly varied and complex array of portfolio analysis indicators, both fundamental and technical analysis. Thus, this condition indicates the need for indicators that are user-friendly, yet reliable enough to produce satisfactory returns on investment for users.

In a corporation, both private and public, there are many instruments that are used in making strategic steps, including asset management and debt inclusion. These two things are also considered in portfolio analysis for investment decision-making. Investors who are unfamiliar with financial statement analysis tend to choose companies that have high asset values without paying more attention to details about these assets and other matters relating to assets. The same thing happens when new investors see debt in the financial statement, the company's ability to pay off debts and how it manages its debt are often ignored. Understanding finance is also a problem that reduces the gap between the newcomer investors and the experienced ones.

Fluctuation in assets indicates changes in a company's operation, regardless of the increase or decrease in the value of the company's assets. The relationship between assets and their productivity is something that cannot be removed by stock analysts, so changes in assets are of great concern to investors, especially those with long-term investing preferences. Technological developments also have an impact on debt as a funding instrument. Various 
and repetitive market maneuvers require prime and robust funding, that is, one that is able to fulfill the company's operating agenda, while at the same time showing good solvency value for creditors. In addition, shareholders assess this aspect as an indicator for determining investment decisions. It has also been recognized that asset procurement is often accommodated by debt. In today's world, where marketing patterns have changed considerably due to the involvement of the internet in information distribution, many companies have made adjustments to enter electronic-based marketing and to utilize the latest technologies. Changes in assets, in order to support this concept, have become an urgency for every company in Indonesia, from listed companies on the stock exchange to Micro, Small, and Medium Enterprises (MSMEs).

The rise of investment platforms that are increasingly accessible to every level of society indicates the need for an adequate understanding of portfolio analysis. Well-known brokerage services including Mirae Asset, IndoPremier, and other stockbrokers have provided portable securities transaction services in order to reach more new investors and provide more real-time transaction facilities. The two aspects above, namely changes in assets and debt solvency are two indicators that are extremely relevant to current investment trends. In addition, the need for user-friendly fundamental analysis indicators for ordinary investors to obtain satisfying returns and attract investment from the society to the capital market makes asset growth and debt solvency important to analyze their relation to the volatility of stock prices.

\section{LITERATURE REVIEW}

The Modigliani-Miller theory explains the capital structure in relation to firm value. Proposition I (Modigliani and Miller, 1958) describes the irrelevance between firm value and capital structure in the absence of taxes, capital costs, agency costs, information asymmetry, and efficient markets. Proposition II explains that without taxes, a high DER will lead to an increase in ROE. Another case with propositions I and II, Proposition III explains that the value of a company will increase if it is financed with debt, if taxes apply. This is because loan interest is subtractive to taxes (tax-deductible), which will increase company profits.

Spence (1973) suggests that companies that have a good performance (superior performance) use financial information to send signals to the market. From his research, it is also found that the cost of signals on bad news is higher than good news and companies that have bad news send signals that are not credible. This motivates managers to disclose private information to reduce information asymmetry in the hope of sending good signals (good news) about the company's performance to the market. Assets are resources that belong to a business. The business uses its assets in carrying out activities such as production and sales. A common characteristic that all assets have is their capacity to generate future services or profits (Weygandt et al., 2015:12). According to Halim (2005:42), asset growth is the annual change (growth rate) of total assets.

Prasetyo (2011:110) explained that company growth is always synonymous with company assets (both physical assets such as land, buildings, edifices and financial assets such as cash, receivables, etc.) Paradigm about asset as an indicator of company growth is commonly used. According to Baridwan (2004:23), debt is a sacrifice of economic benefits that will occur in the future due to the current obligations of a business entity which will be fulfilled by transferring assets or providing services to other business entities in the future. will come as a result of past transactions. According to Kasmir (2015:151), the solvency ratio or leverage ratio is a ratio used in measuring the extent to which company assets are financed with debt. This means how much debt burden the company bears compared to its assets. In a broad sense, it is said that the solvency ratio is used to measure the company's ability to pay all of its liabilities, both short and long term, when the company is dissolved (liquidated). 
According to Darmadji and Fakhruddin (2012:5), shares are a sign of the participation or ownership of a person or entity in a company or limited liability company. Shares are in the form of a sheet of paper which states that the owner of the paper is the owner of the company that issued the securities. Judokusumo (2007:146) defines the share price volatility as a measure of uncertainty about the results obtained from a share.

\section{RESEARCH METHOD}

The type of data in this study is divided into quantitative and qualitative data. Quantitative data is in the form of financial statements of the research sample companies, while qualitative data is a description of the company object. The data in this study were taken from secondary sources, which were obtained from two sources, namely the Indonesia Stock Exchange (IDX) through the official website https://www.idx.co.id/ and The Indonesia Capital Market Institute (TICMI) through the website https://ticmi.co.id/. Data obtained by means of documentation through a summary of the company's performance during the period 20112018. From this report, annual asset growth is obtained from the comparative financial position report, the value of the Debt to Equity Ratio (DER) indicator is obtained from the annual financial position report, and the stock price volatility is obtained from the monthly closing price of shares contained in the details of the traded shares. The population in this study consists of companies listed in the Indonesian Stock Exchange in the financial sector. The total sample included in this population is 94 companies. The sampling technique used was purposive sampling. After going through the sampling process, 6 sample companies were obtained, with 48 observations. The analytical method used is multiple linear regression analysis, with hypothesis testing using the t test to test the significance of the effect of the independent variables on the dependent variable.

\section{RESULTS AND DISCUSSIONS}

\subsection{Result}

Classic assumption test. Normality test is conducted using the one-sample

Kolmogorov-Smirnov Test. Table 1 shows that the 2-tailed Exact Sig. value is 0.283 which greater than 0.05 indicates that the residual value of the sample has been normally distributed.

\section{Table 1. Normality test: One-sample Kolmogorov-Smirnov test}

\begin{tabular}{llr}
\hline N & Mean & 48 \\
& Std. Deviation & 0.0000000 \\
Most Extreme Differences & Absolute & 8.38746136 \\
& Positive & 0.139 \\
& Negative & 0.139 \\
Test Statistic & & -0.124 \\
Asymp. Sig. (2-tailed) & & 0.139 \\
Exact Sig. (2-tailed) & & 0.021 \\
Point Probability & & 0.283 \\
\hline
\end{tabular}

The multicollinearity test was performed and described in Table 2, where tolerance and VIF value obtained were 0,839 and 1,192 , respectively. These results explain that there is no multicollinearity between the independent variables in this regression model, because all independent variables have a tolerance value $>0.1$ and a VIF value $<10$. 
Table 2. Multicollinearity test

\begin{tabular}{lllr}
\hline & \multirow{2}{*}{ Model } & \multicolumn{2}{c}{ Collinearity Statistics } \\
\cline { 3 - 4 } & Constant & \multicolumn{2}{c}{ Tolerance } \\
\hline & GRO & 0.839 & 1.192 \\
& DER & 0.839 & 1.192 \\
\hline
\end{tabular}

Dependent Variable: HV

Picture 1 shows the heteroskedasticity test which depicted with the scatterplot diagram. It resulted in a group of dots which distribution are not patterned or do not form a certain regular pattern (wavy, widened, and narrowed). In addition, the points are scattered over the positive and negative regions of the y-axis, or above and below the zero. These things explain that there are no symptoms of heteroscedasticity (Ghozali, 2016:134).

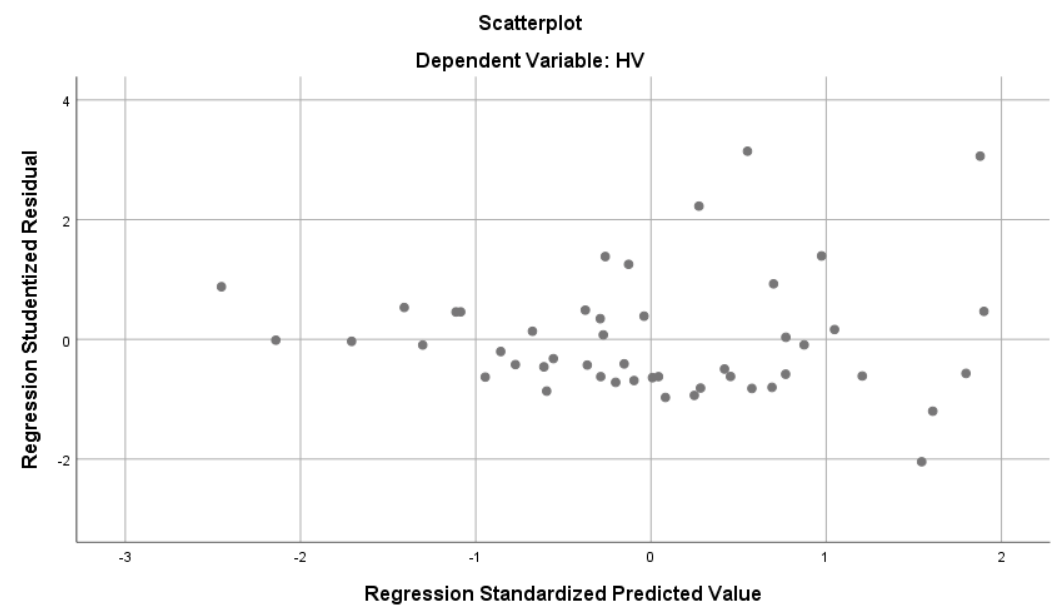

Picture 1. Scatterplot Diagram

Multiple Linear Regression Analysis. Table 3 shows that a constant $(\alpha)$ of 11,712 states that if there is no value for asset growth $\left(\mathrm{X}_{1}\right)$ and debt solvency $\left(\mathrm{X}_{2}\right)$ or equal to zero, the volatility of the stock price $(\mathrm{Y})$ is 11,712 . 2 . The regression coefficient $\left(\beta_{1}\right)$ for asset growth is a positive value of 0.406 , which indicates a positive effect of asset growth on stock price volatility. If the asset growth increases, then the stock price volatility will increase by 0.406 times the asset growth rate, assuming the other independent variables are constant. The regression coefficient $\left(\beta_{2}\right)$ for debt solvency has a negative value, equal to -0.172 , which means that the debt solvency as independent variable and the stock price volatility as dependent variable has a negative relationship. In other words, if the debt solvency score increases, the stock price volatility will increase by -0.172 with the assumption that other independent variables remain constant. The coefficient of determination based on the adjusted $R^{2}$ value is 0.100 . So, both independent variables $X_{1}$ and $X_{2}$ have $10 \%$ determination rate to explain the dependent variable $\mathrm{Y}$, while the remaining $90 \%$ is explained by other factors that are not included in this study.

Based on the results of the partial regression analysis, it is found that the growth of assets has a t value of $2.684>2.014$ and a significance value of $0.01<0.05$, so $\mathrm{H}_{1}$ is accepted because $t_{\text {count }}>t_{\text {table }}$ and a significance level less than 0.05 , It is concluded that asset growth has a significant effect on stock price volatility. On the other hand, on the independent variable debt solvency, the t-value obtained is $-0.172<2.014$ and the significance value is $0.261>0.05$, then $\mathrm{H}_{2}$ is rejected and $\mathrm{H}_{2}$ is accepted because $\mathrm{t}_{\text {count }}<\mathrm{t}_{\text {table }}$ and the level of significance is greater than 0.05 , It is concluded that debt solvency has no significant effect on stock price volatility. 
Table 3. Multiple linear regression analysis

\begin{tabular}{rlrrrrrr}
\hline \multirow{2}{*}{ Model } & & \multicolumn{2}{c}{$\begin{array}{c}\text { Unstandardized } \\
\text { Coefficients }\end{array}$} & \multicolumn{2}{c}{$\begin{array}{c}\text { Standardized } \\
\text { Coefficients }\end{array}$} & & \multirow{2}{*}{ Sig. } \\
\cline { 3 - 6 } & & \multicolumn{2}{c}{ B } & Std. Error & \multicolumn{1}{c}{ Beta } & & \\
\hline \multirow{2}{*}{1} & Constant & 11.712 & 3.287 & & 3.564 & 0.001 \\
& GRO & 0.235 & 0.087 & 0.406 & 2.684 & 0.010 \\
& DER & -0.511 & 0.449 & -0.172 & -1.138 & 0.261 \\
\hline
\end{tabular}

Dependent Variable is HV

$\mathrm{R} \quad 0.372$

R-square $\quad 0.138$

Adjusted R-square $\quad 0.100$

Std. Error of the Estimate 8.57182

$\mathrm{F} \quad 3.604$ significant at $5 \%$

\subsection{Discussion}

Effect of asset growth on stock price volatility. Based on the results, it is known that asset growth has a significant effect on stock price volatility, shown in the t-test result that accepts $\mathrm{H}_{1}$. The entire sample of companies uses the leveraging method in funding their business, so these results prove the MM theory (Modigliani and Miller, 1958) that asset growth in leveraged firms has a significant effect on stock price volatility. In addition, asset growth serves as a good signal in the capital market that can move stock market prices significantly. The results of this study also support the results of previous studies by Anastassia and Firnanti (2014) and Artikanaya and Gayatri (2020).

Effect of debt solvency on stock price volatility. Based on the results, debt solvency has no significant effect on stock price volatility, proven in the rejection of $\mathrm{H}_{2}$ on the result of t-test. The excessive use of debt will endanger the company, because the company will fall into extreme leverage category and it will be difficult to pay off its debts (Fahmi, 2017:72). Companies that are not solvable are companies whose total debt is greater than their total assets (Hanafi and Halim, 2009:81). In investing, investors do not always see the company's dependence on debt but how much the company's ability to generate income, so that the high and low DER ratio does not always cause a reaction to the movement or volatility of stock prices. There are also other factors beside DER that are able to change stock price volatility, such as micro and macroeconomic conditions, expansion policies, sudden changes of board of directors, involvement of directors or company commissioners in a criminal act, continued decline in company performance, systematic risk, and the psychological effects of the market (Fahmi, 2012:89). This research is consistent with the research of Selpiana and Badjra (2018) and Yulinda et al. (2020).

\section{CONCLUSION}

Asset growth has a significant effect on stock price volatility. Investors see asset growth as a good signal, because it indicates an increase caused by profits, income, and procurement of assets through debt or capital. Debt solvency does not have a significant effect on stock price volatility, as evidenced by the result of hypothesis test using partial test. DER is not the only indicator in fundamental analysis, and a high DER will make investors reluctant to invest, so the low volume of stock trading will lead to no significant change in volatility. 


\section{REFERENCES}

Artikanaya, I. K. R. dan Gayatri. (2020). Pengaruh asset growth, leverage, dan dividend payout ratio pada volatilitas harga saham. E-Jurnal Akuntansi, 30(5). 1270-1282. https://doi.org/10.24843/EJA.2020.v30.i05.p16

Anastassia dan Firnanti, F. (2014). Faktor-faktor yang mempengaruhi volatilitas harga saham pada perusahaan publik nonkeuangan. Jurnal Bisnis dan Akuntansi, 16(2). 95-102. http://jurnaltsm.id/index.php/JBA/article/view/80

Baridwan, Z. (2004). Intermediate accounting. Edisi kedelapan. Yogyakarta: BPFE.

Darmadji, T., dan Fakhruddin, H. M. (2012). Pasar modal di Indonesia. Edisi ketiga. Jakarta: Salemba Empat.

Fahmi, I. (2012). Pengantar manajemen keuangan: Teori dan soal jawab. Bandung: Alfabeta.

Fahmi, I. (2017). Analisis kinerja keuangan. Bandung: Alfabeta.

Ghozali, I. (2016). Aplikasi analisis multivariete dengan program IBM SPSS 23. Edisi 8. Semarang: Badan Penerbit Universitas Diponegoro.

Halim, A. (2005). Analisis investasi. Edisi kedua. Jakarta: Salemba Empat.

Hanafi, M. M. dan Halim, A. (2009). Analisis laporan keuangan. Edisi 4. Yogyakarta: UPP STIM YKPN.

Judokusumo, S. (2007). Pengantar derivatif dalam moneter internasional. Jakarta: Grasindo.

Kasmir. (2015). Analisis laporan keuangan. Jakarta: Rajawali Press.

Modigliani, F., and Miller, M. H. (1958). The cost of capital, corporation finance and the theory of investment. The American Economic Review, 48(3). 261-297. https://www.jstor.org/stable/1809766

Prasetyo, A. (2011). Manajemen keuangan bagi manajer non keuangan. Cetakan 1. Jakarta: PPM.

Selpiana, K. R., dan Badjra, I. B. (2018). Pengaruh kebijakan dividen, nilai tukar, leverage, dan firm size terhadap volatilitas harga saham. E-Jurnal Manajemen, 7(3). 16821712. https://doi.org/10.24843/EJMUNUD.2018.v7.i03.p20

Spence, M. (1973). Job market signalling. The Quarterly Journal of Economics, 87(3). 355374. Oxford University Press. https://doi.org/10.2307/1882010

Weygandt, J. J., Kimmel, P. D., and Kieso, D. E. (2015). Financial accounting: IFRS edition. $3^{\text {rd }}$ Edition. United States: Wiley.

Yulinda, E., Astuti, T. P., dan Haryono, S. T. (2020). Analis pengaruh devidend payout ratio, leverage, firm size, volume perdagangan, earning volatility, dan inflasi terhadap volatilitas harga saham pada perusahaan yang terdaftar dalam Indeks LQ 45 tahun 2014. Syntax Literate Jurnal Ilmiah Indonesia, 5(5). 76-83. http://dx.doi.org/10.36418/syntax-literate.v5i5.1106 